\title{
More and more restrictive - but not always populist: explaining variation in the British Conservative Party's stance on immigration and asylum
}

\begin{abstract}
Centre-right parties are commonly inclined toward appeals and policies on immigration that are both restrictive in nature and populist in tone - in part because this is what they believe in, in part because it affords them an electoral advantage over their rivals on the centre-left. One would expect, however, that the extent to which they focus on immigration and asylum will vary according to public opinion, according to who leads them, and according to whether they are in government or in opposition. This would appear to be the case for the British Conservative Party, but the relationship is not an entirely consistent one. Moreover, while the Party has, for half a century, pursued ever more restrictive policies, the extent to which it has couched its approach in populist rhetoric varies considerably over time - and not always in line with the severity of its stance on immigration. The reason for this lies partly in the social and economic liberalism of some of its leaders (and in their related concern to act 'responsibly' on race and immigration) but also in their anxiety not to alienate key sections of the middle classes who must be persuaded to support the Party if it is to win elections. These considerations are likely to weigh heavily with other centre-right parties, too.
\end{abstract}

There has been a great deal written recently about the impact of radical right wing populist parties on the programmes and policies of more mainstream political formations, especially when it comes to the issues of immigration and integration (see, for example, van Spanje, 2010, Bale et al., 2010, and Williams, 2006). But anyone who thinks that it takes a fringe (or formerly-fringe) party to prompt its bigger, older rivals (and not only those located on the right of the political spectrum) into talking and sometimes even acting tough in this regard has either a very short memory or is ideologically-blinkered. In the Nordic countries, for example, social democratic parties, with their traditionally strong links to trade unions, were among 
the first in Europe to insist on the so-called 'immigration stop' which became a common response to the economic difficulties of the early 1970s and which - owing at least as much to those selfsame parties as to their far-right opponents - remains in force today, albeit with qualifications triggered by legal obligations to allow free movement to citizens of an enlarged EU and to consider applications for asylum from increasing numbers of people fleeing civil and international conflicts in the MiddleEast and Sub-Saharan Africa (see Hinnfors et al., 2012).

Flight from danger and persecution, and indeed free movement, of course, is nothing new. Nor is a modicum of moral panic about such things. Indeed, it was precisely such a panic (see Collyer, 2005) that encouraged one of Britain's mainstream political parties - in office long before the populist radical right that currently gains so much media and academic attention made its appearance on the scene - to issue the following election leaflet:

\section{LET ‘EM ALL COME}

Is the Radical Cry

The Radicals, by their obstruction to the Aliens Bill, are evidently glad to see all foreigners who are criminals; who suffer from loathsome diseases; who are turned out in disgrace by their fellow countrymen; who are paupers; who fill our streets with profligacy and disorder.

The Radical Welcomes Them All 
The Unionist Government wants to keep these creatures out of Great Britain. They don't want to see the honest Britisher turned out by these scourings of European slums. They brought in a bill to check this evil flow of aliens.

But the Radicals said no!....

Next Session, the Government will bring in the Bill again. Show your disgust of Radical tactics, and

\section{SUPPORT THE UNIONIST GOVERNMENT}

Using the UK Conservative Party, which produced this election leaflet back in 1904 (see McKenzie and Silver, 1968: 60), as a case study, this article suggests that the centre-right in Europe has long been inclined toward appeals and policies on immigration that are both restrictive in nature and populist in tone. It then goes on to discuss the circumstances in which it is more or less likely to campaign hard on immigration and asylum, focusing in particular on public opinion, on the question of leadership, and on whether the Party is in government or in opposition. As that discussion makes clear, however, we also need to explain the extent to which the Tories have, by and large, resisted the temptation to press home their obvious advantage on such issues - a puzzle first posed (but left unsolved) some thirty years ago by two eminent psephologists (see Crewe and Särlvik 1980). On the evidence available from archival and other sources - the detail of which can be consulted in two recent books on the Tories (see Bale, 2010 and Bale 2012) - the Party's historic reluctance to go all-out on immigration, stems partly from the social and economic liberalism of some of its leaders (and from their concern to act 'responsibly' on the issue) and partly from their concern not to alienate the well-heeled and well-educated middle-class voters whose support was (and is) crucial to electoral success. 


\section{Context - international and historical}

To those who study migration and/or party politics in its comparative context, the fact that the British Conservative Party took a tough line on immigration, and sometimes couched it in pretty populist tones, before UKIP (or, indeed the British National Party or its forerunner, the National Front) came on the scene will come as no surprise. Nor will the fact that it has continued with that line even though the electoral impact of such parties has been minimal. After all, as Akkerman reminds us in a recent article (2012: 516),

Christian Democratic and Conservative parties are also authoritarian and nationalist. [C]entreright parties are preoccupied with restricting immigration because their ideological raison d'être is to defend national security and national communitarian values. Policy differences regarding immigration and integration between the mainstream and radical right can be perceived as a matter of degree rather than as outcomes of diverging ideological perspectives.

Moreover, as her research also reveals, in recent years, right-wing governments, even those which do not include a radical right-wing populist party either as a full blown coalition partner or as a support party, have tended to pursue restrictive and assimilationist policies on immigration and integration - more so, at least, than have governments of the centre or centre-left.

That said, we need to exercise a little caution. For one thing, as we noted in our introduction, not every centre-left party and government in Europe, especially in the Nordic countries, has plumped for an 'open door' policy, particularly when it comes to labour migration. For another, as others have noted (see, for example, Spehar et al., 
forthcoming), the commitment of Europe's centre-right (for which read conservative, Christian democratic and market liberal) parties to closing (or preventing the opening) of that open door is far from total. A recent study of Sweden (Odmalm, 2011) is just the latest reminder of many that centre-right parties are cross-pressured on this issue. They are tempted, he notes, to emphasise immigration and integration at elections if they are seen by voters as particularly competent in their handling of them especially when polls reveal, not only their lead on, but also the salience of, such issues. On the other hand, trading on those issues can turn out to be very tricky either because they risk opening up internal ideological disputes (for example, on the merits of preserving traditional values and borders versus the need for economic dynamism) or because talking about them courts uncomfortably credible accusations of xenophobia and racism from their opponents that may resonate with some of those whose votes they sorely need. Moreover, the parties in question may 'own' other issues (for example, the economy and/or public services) which - perhaps because they are less tricky, perhaps because they are actually more fruitful electorally - they would on balance prefer to selectively emphasize.

On the other hand, of course, they may not always enjoy the luxury of choice since migration flows are notoriously path-dependent (in the sense of being shaped by decisions taken - or not taken - long ago), as well as dependent on factors beyond the control of a single nation state. In the case of the UK in the post-war era, for instance, Conservative governments in the late 1950s were coping with the legacy of the 194551 Labour government's British Nationality Act which offered any British subject (a category that included millions of people born in the current and former British Empire) the right to a British passport and theoretically unfettered entry to the "mother 
country' in order to live and work. This, combined with labour market shortages created by the post-war boom, fuelled the first wave of post-colonial immigration into the UK from the Carribean and South Asia - a phenomenon that the Tories' first attempt to correct the situation (the Commonwealth Immigrants Act of 1962) ensured would be permanent by, among other things, 'locking in' generous rights to family reunification.

Fast forwarding thirty years, John Major's Conservative government was faced, like many other European democracies at the time, with the influx of asylum-seekers produced by the eruption of civil wars and international conflict that was triggered by the end of the Cold War, most obviously in Africa and in the Balkans. In opposition after 1997, the Conservatives would have been obliged, whatever their feelings on the issue, to respond to what amounted to the UK's third sudden wave of immigration, namely the arrival of hundreds of thousands of Central and East Europeans triggered by the Labour government's decision, when the economy was booming, not to follow other member states in imposing labour market restrictions following the expansion of the EU - an expansion heartily approved, it should be said, by the Tories on the grounds that widening the Union would hopefully make its deepening less likely.

\section{Populism and Conservatism: a long love affair}

As a brief glance at any good history of the Conservative Party (see for example, Ramsden, 1998) quickly reveals, a combination of populism and nationalism has long been woven into Tory ideology. From the nineteenth century onwards, the Conservatives' identity was to some extent founded on their opposition to a Liberal 
Party which for decades was associated (not least by Tory politicians) with, on the one hand, an industrial elite who had no intention of paying to improve the lot of the common man, and, on the other, spoilsport non-conformists, who had no sympathy with his ordinary pleasures (the most obvious of which revolved around the drink with which Tory-supporting farmers and brewers were more than happy to supply him). This useful frame became increasingly important as the electorate expanded with the 1867 Reform Act daringly passed by Tory Prime Minister Benjamin Disraeli, whose governments were also responsible for welfare measures which helped (at least until the New Liberalism took hold at the turn of the century) that his party cemented its reputation as wanting to better 'the condition of the people'. Disraeli also played a vital part in ensuring that it was the Conservatives who became not just the party of 'the nation' (as opposed, for instance, to 'the classes') but also the party of Empire and the often aggressive English and British nationalism which went with it. It was also the Conservatives, albeit under rather less inspiring leadership, who made the first serious attempts to control immigration - for the most part Jewish immigration into the country in 1894, 1904 and then, successfully, in 1905.

The First World War saw the Conservative Party called into coalition to save the country from a Liberal Party which was clearly incapable on its own of meeting the demands of total war, thereby enhancing the Tories' nationalist and patriotic credentials (see Keohane, 2010). A decade or so later the country’s only General Strike was faced down by a Conservative Prime Minister, Stanley Baldwin, whose skilful use of rhetoric reduced the unions (or at least their misguided leaders) to a 'them' bent on disrupting and even subverting 'us' (see Williamson, 2007). After a brief interregnum, Baldwin then became the effective and then the titular leader of a 
'national government', which took over following the fall of Labour's minority administration in 1931, using his considerable communication skills to strengthen the Tories' connection with a mythical (but nonetheless powerful) 'heartland' that experts on contemporary populism routinely point to as one of its essential components (Taggart, 2000 and Mudde, 2004).

All this clever crafting of the Conservative brand could have been undone - and for a while was seriously undermined - by the national government's policy of appeasement toward Europe's fascist dictators in the mid to late 1930s. However, the Tories were saved by the dissent displayed by, and the eventual accession to the premiership of, Winston Churchill (Ball, 2001). Although, like Disraeli, Churchill had little real understanding of the lives lived by ordinary people he was similarly capable of connecting with them and re-vivifying the national myth - in his case built around the bulldog spirit that would defy and eventually defeat those threating 'our island home'. That vision was, of course, insufficient to bring electoral victory in the immediate aftermath of the Second World War but within a few short years the Conservatives, still led by their iconic wartime leader, were able to convincingly claim to want to 'set the people free' from the supposedly excessive bureaucracy and controls entailed by a socialism still portrayed as alien and incapable of understanding the national character.

What Churchill was unable to do after he got back into office in 1951, however, was to convince enough of his colleagues (most of whom had more enlightened views on race than he did and were also more concerned about labour shortages than he was) that the government should take urgent action to limit immigration from the 'New 
Commonwealth' - Britain's current and former colonies in the Indian sub-continent, Africa, and the Caribbean. This failure (if failure it was) was less serious than it might have been, however, because the only politicians campaigning in the mid- to latefifties for an end to 'coloured' immigration were a handful of Tory MPs, while Labour continued to defend the liberal internationalism enshrined in the 1949 British Nationality Act that had facilitated that influx in the first place (Roberts, 1995: Chapter 4). It was also the case that outside a few urban hot-spots where public disturbances attracted understandable attention from politicians, press and police alike, public concern remained relatively muted until the end of the decade (see Spencer, 1997).

In any case, there were plenty of other things going on at the time, at least two of which merit a mention when tracing the Conservatives' long love affair with populism. Firstly, the Suez conflict, while it proved something of a fiasco owing to Prime Minister Anthony Eden's failure to secure US backing for armed intervention, at least allowed the Tories to counterpose their military patriotism with the apparent pacifism of a Labour Party already tearing itself apart over a nuclear deterrent regarded as an unfortunate necessity by most voters. Secondly, Eden's successor, Harold Macmillan, notwithstanding his private doubts about where it was all leading, was publicly happy to exploit the sheer novelty and fun that accompanied rising mass affluence in order to draw a powerfully populist, but by no means unprecedented, contrast between a Conservative Party happy to let the good times roll and give people what they wanted and a Labour Party which for the most part still frowned upon consumerism and clung to the idea that they should instead be given what they supposedly needed. It is often said that British socialism owed more to Methodism 
than to Marx, but what is less often noted is that the former may have been just as damaging to its electoral appeal as the latter.

That said, Macmillan, especially in the wake of the Conservatives' second consecutive landslide victory in 1959, did not have it all his own way. The Tories' leader was forced by the logic of his own strategic analysis of the UK's post-Suez potential into accelerating the 'end of empire' and attempting - belatedly - to join the EEC. As a result, he was obliged to sacrifice some of his party's populist political capital and even (when it came to 'Europe') to cede some of it to a Labour leader, Hugh Gaitskell, prepared to promise the British people that he (unlike Macmillan) would refuse to sacrifice 'a thousand years of history'. De Gaulle's decision to veto the UK's application, and the Tories' determination eventually to undo it, merely ensured that Labour could continue taunting them.

What Macmillan did succeed in doing, however, was associating the Conservative Party in the public mind with a greater willingness to control immigration at the same time as effectively ensuring its inevitable increase. Acting - without much enthusiasm it must be said - in response to rising public concerns about immigration picked up in polls and on the doorstep at the 1959 general election, the Conservative government eventually agreed to risk the wrath of other countries and announced that it would shortly be introducing what became the Commonwealth Immigrants Act. In so doing, it created the so-called 'beat the ban rush' which saw thousands of migrants (some from the West Indies and Africa but most from India and Pakistan) make the trip to 'the mother country' while it was still possible for them to do so. The fact that most of them were young men who would, even under the new legislation, be able 
later to bring in wives and other family members ensured more ethnic minorities would enter the country in decades to come and, as a result, that Britain would in fairly short order become a multiracial society.

Very few Conservatives, especially grassroots members and supporters, were happy about this, of course. And because voters shared those misgivings, and because the Party at Westminster was prepared to respond (their opponents would say pander) to their concerns, the ongoing influx and increasing presence of ethnic minorities meant that immigration would remain an important issue - sometimes latent, sometimes manifest - in British politics. Yet it was also one which was more likely to benefit the Tories rather than Labour. In short, the Conservative Party did just as much as its main rival to create what many voters regarded as a mess but would go onto get far more credit for promising - sometimes loudly, sometimes less so - to clear it up.

\section{Explaining variation}

The extent to which the Conservatives have, since the early 1960s, been prepared to press home their advantage on immigration - and to do so in populist fashion - has varied (albeit, as we will show below, not entirely consistently) according to three things:

(1) whether the issue has risen in salience in terms of public opinion, whether that rise is triggered by a significant and genuine upsurge in numbers and whether it is registered 'scientifically' (for instance, via polls) or unscientifically (via the media or contact with the public and ordinary party members) or a 
combination of both (for example, via the Party's ex ante anticipation as well as its ex post analysis of election results);

(2) whether the leader of the Party has been personally keen - or at least prepared - to reflect and even to exploit public opinion; and

(3) whether the Party has been in opposition rather than in office.

\section{Public Opinion}

Macmillan's government was worried about the reaction of governments overseas especially in the Commonwealth itself, as well as the USA - to any attempt to limit immigration, and only did so when feedback from the 1959 election, from polls and from the press, suggested that delay in stemming the increasing flow of 'coloured' immigrants would worsen the a precipitate post-election loss of support caused mainly by economic difficulties. Likewise, the visible tightening of the Party's policy on immigration after 1968 (it not only promised that work permits would no longer confer an eventual right to settlement and that resources would be made available for 'voluntary repatriation' but declared 'There will be no further large scale permanent immigration') occurred at least partly in response to the groundswell of public and party support for Enoch Powell, whose incendiary 'Rivers of Blood' speech (made in the wake of a crisis created by the flight of Asians fleeing Kenya's 'Africanization' policy) saw him sacked from the Tory Shadow Cabinet. A tighter policy still (headlined by a promise to review British nationality legislation) was hinted at in October 1974 after the election earlier that year (held less than two years after a 
Conservative government had been obliged to allow in tens of thousands of Asians fleeing Uganda) had seen the Party lose valuable seats to Labour in Powell's West Midlands heartland - precisely where the swing to the Conservatives had been so strong in 1970 (see Studlar, 1978). However, what the Tories offered voters in 1974 was as nothing to the even more restrictive (and far more specific promises) spelled out in the Party's 1979 manifesto. These were made in the wake of rising public concern (reflected in polls, in the press and in an evanescent flurry of support for the far-right National Front) about the evident inability of governments of either stripe to prevent both immigration and its inevitable concomitant - a culturally (and visibly) more diverse population.

Public antipathy toward immigration never disappeared but declined significantly in salience until the mid- to late-1990s. By then many people - especially younger and better educated people - were more reconciled to a multicultural Britain, and the focus of that antipathy switched accordingly. At first, the spotlight was on the huge (and allegedly unwarranted) increase in applications for asylum prompted by a combination of international conflict and global inequality. Partly in response - but also because they were forced by Labour's huge leads on the economy and public services to focus on any halfway-salient issue on which they could plausibly claim to be more in tune with the electorate - the Tories began to parrot and prompt tabloid talk about the 'bogus asylum-seekers' who went on to feature in their highly populist 2001 manifesto, Time for Common Sense. Thereafter, as asylum applications began to fall, and following the Labour government's decision not to impose transitional controls on free movement of EU citizens in 2004, attention moved to the 'flood' of East European workers triggered by the accession of ten new member states. Hence, 
the Tory manifesto in 2005, It's Time for Action, concentrated on immigration as well as asylum. The former was to be regulated by a points-based system and the latter dealt with, first, by processing asylum applications offshore and, second, by Britain withdrawing from the 1951 Geneva Convention. In both campaigns, however, the Tories' discourse was shot through with an equal measure of populism. Labour was associated with a politically-correct and incompetent 'liberal elite' who were supposedly intent on turning the country into 'a foreign land' (to quote from a heavily-spun speech by Tory leader William Hague in) and (to quote from an equally controversial election poster approved by one of his successors, Michael Howard) apparently convinced that it was 'racist to impose limits on immigration' when the rest of us (and of course the Conservatives) knew full well that it was simply 'common sense'.

As a result of the numbers pouring in from the new member states and the Labour government's evident failure to deport both foreign criminals and those whose applications for asylum had been rejected - a failure symbolised by a number of scandals and subsequent ministerial resignations - immigration remained high on pollsters' lists of the electorate's most pressing problems and therefore a prime target for the Conservative assault on Labour's increasingly unpopular administration. True, under Cameron, who was (rightly) worried that the populist pitch on immigration had alienated the educated middle-class voters he was determined to win back, the subtler 'dog-whistle' replaced the megaphone. But, with the Party promising a 'grown-up debate' after a period of (it hoped) 'detoxifying' silence on the issue, there was never any danger that it would completely decommission one of the most potent weapons in its armoury. When, in 2007, it looked like Labour might call an early election to 
exploit the temporary boost in popularity afforded by a change of lead by its swapping Blair for Brown, it was to immigration (and only then tax) that the Conservatives first turned, with their leader, having failed to mention the issue until then, suddenly expressing his empathy with worried voters. By 2010, the Party had opted to assume a highly restrictive stance on immigration, promising (in reasonable tones and driven, it was claimed, by the need to ease pressure on 'our public services' brought about by all those Polish plumbers and pickers of fruit) to cut net migration form the hundreds of thousands to 'tens of thousands'. This stance, it was hoped, would give the Tories the best of both worlds, namely the thumbs up from (largely) working class authoritarians and the acquiescence (if not necessarily the enthusiasm) of middle class liberals.

\section{Leader}

The fact that Cameron dialled down the rhetoric but pumped up the policy, moving away from the populist words but simultaneously (and very unusually) risking a commitment to a specific and highly restrictive target, represented more than a repositioning exercise - an attempt to have his cake and eat it too (Bale et al., 2011). It also reflected social attitudes shared with his closest colleagues. Since 2005, the Conservative Party leadership has largely been made up of forty-something men and women for whom 'traditional' attitudes on race in particular are as unthinkable as they are unsayable. Interestingly, however, this is nothing new. The current Cabinet's social liberalism is not unprecedented. Anyone looking through the minutes meetings attended by many (though not all) of those who operated at the top of the party from the late 1950s onwards, as well as through their memoirs and biographies, soon 
realises that 'progressive' views were really very common decades ago. They reveal - particularly in the wake of the 1964 election where one renegade local association had bucked the trend in the West Midlands by suggesting to voters 'If you want a nigger for a neighbour, vote Labour' - a marked distaste for anything that smacked of 'playing the race card' and irresponsibly disturbing a delicate (and to some extent bipartisan) balance of stricter controls and stronger anti-discrimination measures. This was so much the case, indeed, that Margaret Thatcher - infamous among liberals for a 1978 television appearance in which she acknowledged that that 'people are really rather afraid that this country might be rather swamped by people with a different culture' - comes over as something of a throwback to a bygone age, albeit one whose instincts (on this as on so many other matters) were more in tune with those of the grassroots than were those of her (Shadow) Cabinet colleagues. True, the fact that she was summarily replaced by the more liberal John Major is easily forgotten in the face of his eventual replacement by more self-consciously Thatcherite (and therefore populist) leaders of the Party who followed him - Hague, Duncan Smith and Howard. But Cameron's election has to be seen, in this respect at least, as the resumption of normal (more 'progressive') service.

Ultimately, however, Cameron, like Heath (and Macmillan) before him, has not allowed his evident social (and, indeed, economic) liberalism to interfere with his equally evident strategic decision to move the Party toward a more restrictive stance on immigration. This suggests that it is a little too easy to assume that the Tories' substantive stance on the issue in the end simply reflects the preferences of their leader. On the other hand, there is no doubt that the latter influences the symbolism of the Party's approach. Whether or not the latter can convincingly be characterised as 
populist (as well as simply restrictionist), in other words, does indeed depend on who is in charge.

Heath's short-lived predecessor as leader, Alec Home, for instance, is widely remembered as decent if rather ineffectual - an image which makes it easy to forget a tough speech he made in February 1965, which called not just for tighter controls but also for government-assisted voluntary repatriation. Heath's accession to the leadership put a lid on this nascent populism, even as policy became more restrictive, although it re-emerged with a vengeance when Enoch Powell launched his campaign to save the nation (and his party) from itself in the spring of 1968. If anything, however, Powell's intervention ruled out a thoroughgoing populist approach by the Party, not least because Heath made a point of distinguishing himself from a man he regarded as a dangerous maverick. Margaret Thatcher had concerns about Powell, too, but she recognised that he had tapped into a rich seam of public feeling and that it was not one which should be ignored. And given how closely they were created in her image, it is entirely predictable that the accession of Hague, Duncan Smith and Howard saw the Party not simply promise to tighten policy - all Tory leaders, beginning with Macmillan, have eventually done that - but to accompany that promise with a characteristically populist promise to wrest control of immigration from a bien-pensant elite which, by letting people in, has let the people down.

\section{Government and Opposition}

But the party's propensity to adopt restrictive policy and populist rhetoric is not solely down to its desire to capitalise on public concerns prompted by rising numbers and/or the ideological sympathies of its leaders. It also depends partly on whether the Party 
is in office or in opposition. This is because, when it comes to immigration (and asylum), to govern is very often not to choose. Once in Downing Street, words no longer suffice and a party's best-laid plans can be blown apart by a combination of international crises and international obligations. Equally, the desire to promote economic growth can trump the desire to protect the nation's borders. In the late 1950s, for example, the emphasis was on filling labour shortages and not endangering foreign policy goals. This was one reason perhaps why the passing of the Commonwealth Immigrants Act by the Conservative Government was, in the 1964 manifesto, afforded just a couple of sentences (albeit ones that reminded voters that Labour had opposed it) and buried under the heading 'Regional Development'. In 1972, the Heath government's decision to allow in tens of thousands of Ugandan Asians sparked resignations and hostile resolutions from constituency associations all around the country. But the government stuck to its guns because, as well as being keen to do the right thing by their progressive consciences, ministers were told by the Attorney-General that they had no choice under international law, and by the Foreign Secretary that to do anything else would have a devastating impact on Britain's reputation within the international community.

Heath's successor, Margaret Thatcher, was simply more fortunate than he was in this respect. Her administration's overtly restrictive 1981 British Nationality Act could so easily have been (but in the end was not) undermined by legislation passed in 1990 to allow an even greater number of Hong Kong residents and their families free entry into the UK if things became too difficult after the Colony's handover to China. Major's government, on the other hand, had to cope with major civil conflicts unfolding in both the Balkans and Africa. These, along with ever-improving communications and transportation, as well as a strengthening UK economy, gave rise 
to more and more claims for asylum of the kind that are very easy for opposition parties to criticize but very hard for governments to manage.

Certainly, it is rare indeed for the Conservative Party in office to make as big a deal of immigration as it does when it is out of it - which is why the Cameron government's apparent willingness to make so much of its ongoing programme to crack down on student visas, family re-unification, and points-based labour migration is so interesting. As the parliament wears on, such measures look less and less likely to deliver the huge reduction in numbers promised at the 2010 election. Therefore one can only presume that the decision has been taken - predicated on the (not unreasonable) belief that Labour's rather half-hearted attempt to reposition itself on the issue will not wash with voters - that they will reward the Tories for trying and forgive them for failing. Whether this happens may depend partly on whether the country's print media have turned against the Party by the time of the next election, in which case they will almost certainly pick it up as one of the many sticks with which they will be able to beat the Government. On the other side of the equation, the increasingly bureaucratic means by which it hopes to meet its target are already infuriating businesses and universities, who are claiming to anyone who will listen that they (and therefore the British economy) are missing out in the race to recruit global talent. Moreover, even in advance of any detectable shortages of low-paid foreign workers in the retail, hospitality, child- and elder-care, and construction and maintenance sectors patronised by the country's middle classes, some former Tory modernisers have begun to worry out loud that the Conservatives risk regaining their unwelcome reputation as 'the nasty party' (Birrell, 2012). This one, as they say, could go either way. 
Were the boot to be on the other foot, however, and a Labour government were similarly struggling, few (especially those who remember how the Conservative Party played things between 1997 and 2005) would expect a Tory opposition to be showing it any mercy. Such an assumption, however, might be wrong - or at least not wholly right. The willingness of the Party under Hague, Duncan Smith, and Howard to open up all guns blazing on immigration was, in the post-war era anyway, somewhat unusual. Ted Heath and most of his Shadow Cabinet, for instance, were initially furious with Powell for opening what they regarded as a Pandora's Box and, even as they tightened policy, continued to worry about alienating the kind of well-intentioned middle-class voter who might have voted Liberal in 1964 and then Labour in 1966 and who the Party desperately needed to win back. Likewise, many of Thatcher's colleagues - not least Willie Whitelaw who, as Shadow Home Secretary, was responsible for immigration policy - appreciated its electoral potential but were also determined not to open themselves and the Party to accusations that they were acting irresponsibly. Indeed, Thatcher's now notorious intervention on the issue in 1978 represented a (successful) attempt on her part to bounce them into taking a harder line than they were really happy with.

As we have suggested, the willingness of those who led the Party between 1997 and 2005 to go further reflected not only their ideological instincts but also a degree of desperation. The latter was brought on by their inability to locate any other significant issues (other than law and order and - at a stretch - Europe) on which they had the measure of a Labour Party led by Tony Blair. It may also have been influenced by the fact that, although Blair's government clearly had trouble persuading people that it had got the situation under control, it was willing (not unlike the first Wilson government, one should add) to continually talk (and sometimes even 
act) tough on immigration and asylum (see Jennings, 2009). This obliged the Tories, if they were to maintain their hardline reputation on such issues, to ramp up the rhetoric and adopt an even more restrictive position than they might otherwise have plumped for. Hague, Duncan Smith and Howard also faced pressure from rightwingers in the Party who were convinced that, unless it did so, it would haemorrhage voters to the highly populist (but not, in truth, particularly popular) United Kingdom Independence Party (UKIP) - an argument still made (mostly by exactly the same right-wingers) today but for which there is as yet little hard evidence (see Goodwin, 2012).

\section{Conclusion}

The way the British Conservative Party has handled immigration over the last half century neatly illustrates the conflicting pressures that mainstream governing parties of the centre-right face on the issue. The Party operates in an island nation which has had trouble reconciling itself to the multicultural reality of its post-colonial present and in a majoritarian and adversarial two (or two-and-a-half) party system which would appear to provide even more incentives to flirt with populism than exist in the

relatively consensual and more broadly-based systems that exist elsewhere in Europe (Rooduijn et al., forthcoming). It is therefore unsurprising that, as we have shown, the Party has tended to argue, sometimes in particularly populist language, for greater restriction - especially in periods where the public has been particularly concerned about the numbers trying to enter the country, and in periods where it is in opposition and/or led by a politician happy (or at least prepared) to reflect that concern. 
Yet - for the most part - the Tories have refused to go as far as they might, and certainly as far as radical right wing populist parties now routinely go. We began with a no-holds-barred leaflet produced before the First World War, but the story since the Second World War is one of a party which, notwithstanding the efforts of some of its more vociferous parliamentary and grassroots members to get it to go further, has largely pulled its punches. True, the temptation to hit harder has been there, particularly recently when it sometimes seemed as if there were no other issues on which the Party could capitalise. But, generally speaking, the gloves have almost always stayed on.

Tory leaderships have been aware of the potential immigration has had, especially since the 1960s, to attract significant numbers of voters whose authoritarian attitudes are capable of trumping views on the economy and the welfare state that would see them lean more naturally towards Labour. However, they have been equally aware (the more so since polling has become routine) that an all-out assault on migration and multiculturalism might alienate other voters on whom the Party relies just as much namely the more liberal middle-classes who like to think of themselves as tolerant and broad-minded and who can also see the upsides of immigration, whether they be cultural or economic. Moreover, as access to higher education and middle-class lifestyles has increased over time, and as young people in particular take living in a multi-ethnic society as a given, this is a group of voters which constitutes a growing proportion of the population. Indeed, they are now joined by increasing numbers of ethnic minority voters whose votes the Party will need if it is to stand a chance of running (or helping to run) the country in the future. This reality - no doubt unpalatable to some traditionalists - was first noted by a few brave (but prescient) 
souls working in its short-lived 'Community Affairs Department' back in the 1970s. Forty years later, it may be, and certainly should be (see Ashcroft, 2012), on the way to becoming common wisdom among those concerned with the Party's long-term viability as an electoral and governing force.

It would be wrong to assert that the same challenge faces the centre-right everywhere in Europe. After all, the size (and to some extent the voting) of ethnic minorities varies significantly, as does the proportion of people who benefit from higher education - an experience which seems to predispose its consumers to more liberal social attitudes. However, in those countries that, like the UK, are becoming both multi-ethnic and highly-educated societies in which populist rhetoric risks alienating as many people as it attracts, conservative, Christian democrat and market liberal parties will increasingly need to think twice before talking as tough as some of their supporters would like.

\section{References}

Akkerman, T. (2012): Comparing radical right parties in government: immigration and integration policies in nine countries (1996-2010), West European Politics, 35 (3), pp. 511-529.

Ashcroft, M. (2012) Degrees of Separation. Ethnic Minority Voters and the Conservative Party, available online at http://lordashcroftpolls.com/wpcontent/uploads/2012/04/DEGREES-OF-SEPARATION.pdf 
Bale, T. (2010) The Conservative Party from Thatcher to Cameron (Cambridge: Polity Press).

Bale, T. (2012) The Conservatives since 1945: the Drivers of Party Change (Oxford: Oxford University Press).

Bale, T., Green-Pedersen, C. Krouwel, A. Luther, K.R. and Sitter, N. (2010) If you can't beat them, join them? Explaining social democratic responses to the challenge from the populist radical right in Western Europe, Political Studies, 58 (3): 410-426.

Bale, T., Hampshire, J. and Partos, R. (2011) Having one's cake and eating it too: Cameron's Conservatives and immigration, Political Quarterly, 82 (3), pp. 398-406.

Ball, S. (2001) Churchill and the Conservative Party, Transactions of the Royal Historical Society, 11, pp. 307-30.

Birrell, Ian (2012) The Tories are becoming the 'nasty party' on immigration, Guardian, 11 June, p. 23, available online at http://www.guardian.co.uk/commentisfree/2012/jun/10/tories-nasty-party$\underline{\text { immigration-families }}$

Collyer, M. (2005) Secret agents: anarchists, Islamists and responses to politically active refugees in London in Ethnic and Racial Studies, 28 (2), pp. 278-303. 
Crewe, I. and Särlvik, B. (1980) Popular attitudes and electoral strategy in Z. LaytonHenry (Ed) Conservative Party Politics (London: Macmillan).

Goodwin, Matthew J. (2012) With all this talk of UKIP..., http://www.matthewjgoodwin.com/2012/04/with-all-this-talk-about-ukip.html

Hainmueller, J., and Hiscox (2007), M.J. Educated preferences: explaining attitudes toward immigration in Europe, International Organization, 61 (2), pp. 399-442. Hinnfors, J. Spehar, A. and Bucken-Knapp, G. (2012) The missing factor: why social democracy can lead to restrictive immigration policy', Journal of European Public Policy, 19 (4) pp. 583-603.

Jennings, W. (2009) The Public Thermostat, Political Responsiveness and ErrorCorrection: Border Control and Asylum in Britain, 1994-2007, British Journal of Political Science, 39 (4), pp. 847-870.

Keohane, Nigel (2010) The Party of Patriotism. The Conservative Party and the First World War (Farnham: Ashgate).

McKenzie, R.T. and Silver, A. (1968) Angels in Marble: Working Class Conservatives in Urban England (London: Heinemann).

Mudde, C. (2004) The populist zeitgeist, Government and Opposition, 39 (4), pp. 542-563. 
Odmalm, P. (2011) Political parties and 'the immigration issue': issue ownership in Swedish parliamentary elections, 1991-2010, West European Politics, 34 (5), pp. 1070-1091.

Ramsden, J. (1998) An Appetite for Power: A New History of the Conservative Party (London: Harper Collins).

Roberts, A. (1995) Eminent Churchillians (London: Simon and Schuster).

Rooduijn, M., de Lange, S.L., and van der Brug, W. (forthcoming) A populist zeitgeist? Programmatic contagion by populist parties in Western Europe, Party Politics.

Spehar, A., Bucken-Knapp, G. and Hinnfors, J. (forthcoming) Ideology and entry policy: why non-socialist parties in Sweden support open door migration policies, in U. Korkut, G. Bucken-Knapp, J. Hinnfors, A. McGarry and H. Drake (Eds.) The Discourses and Politics of Migration in Europe (New York: Palgrave/NYU).

Spencer, I.R.G (1997) British Immigration Policy since 1939. The Making of MultiRacial Britain (London: Routledge).

Studlar, D.T. (1978) Policy voting in Britain: the colored immigration issue in the 1964, 1966, and 1970 general elections, American Political Science Review, 72 (1), pp. 46-64. 
Taggart, P. (2000) Populism (Buckingham: Open University Press).

Van Spanje, J. (2010) Contagious parties. Anti-immigration parties and their impact on other parties' immigration stances in contemporary Western Europe, Party Politics, 16 (5), pp. 563-586.

Williams, Michelle Hale (2006) The Impact of Radical Right-Wing Parties in West European Democracies (New York: Palgrave/NYU).

Williamson, Philip (2007) Stanley Baldwin (Cambridge: Cambridge University Press). 